\title{
Population biology and relative growth of the crab Minuca mordax (Smith, 1870) (Crustacea, Decapoda, Ocypodidae) in the Igaraçu River, Parnaíba, state of Piauí, Brazil
}

\author{
Sidely Gil Alves Vieira dos Santos ${ }^{1}$ \\ Luiz Gonzaga Alves dos Santos Filho ${ }^{1 *}$ \\ Lissandra Corrêa Fernandes-Góes ${ }^{2}$ \\ João Marcos de Góes ${ }^{1}$ \\ ${ }^{1}$ Universidade Federal do Delta do Parnaíba \\ Avenida São Sebastião, 2819, CEP 64.202-020, Parnaíba - PI, Brazil \\ ${ }^{2}$ Universidade Estadual do Piauí, Campus Universitário Professor Alexandre Alves de Oliveira \\ Avenida Nossa Senhora de Fátima, CEP 64.202-220, Parnaíba - PI, Brazil \\ * Autor para correspondência \\ luizgonga@ufpi.edu.br
}

Submetido em 17/09/2019

Aceito para publicação em 02/04/2020

\section{Resumo}

Biologia populacional do caranguejo Minuca mordax (Smith, 1870) (Crustacea, Decapoda, Ocypodidae) no rio Igaraçu, Parnaíba, PI, Brasil. O presente estudo teve como objetivo investigar a biologia populacional de Minuca mordax no Rio Igaraçu, Parnaíba, PI, analisando a distribuição de frequência em classes de tamanho, período reprodutivo, crescimento relativo, maturidade sexual morfológica, razão sexual e heteroquelia. Os animais foram coletados manualmente de forma aleatória por duas pessoas durante 1 hora, nos meses representativos da estação seca (setembro a novembro) e chuvosa (abril a junho). Em laboratório os caranguejos foram identificados, separados quanto ao sexo e mensurados. Um total de 610 exemplares foi capturado, sendo 453 machos e 157 fêmeas. O tamanho médio da largura de carapaça (LC) diferiu significativamente $(\mathrm{p}<0,05)$ entre machos $(17,21 \pm 3,68 \mathrm{~mm})$ e fêmeas $(15,06 \pm 3,18 \mathrm{~mm})$. A distribuição dos caranguejos em classes de tamanho foi unimodal para ambos os sexos. A maturidade sexual morfológica obtida para os machos foi de 12,42 mm de LC e para as fêmeas foi de 10,05 mm de LC. A razão sexual para a população foi de 1:0,35 (macho:fêmea), sendo verificada diferença significativa da proporção esperada de 1:1. A heteroquelia foi verificada apenas nos machos da espécie (224 destros e 229 sinistros). Posteriormente, outras observações in loco foram realizadas mensalmente, de fevereiro/2011 a janeiro/2012 para observação de fêmeas ovígeras e determinação do período reprodutivo. Fêmeas com ovos foram observadas apenas nos meses de março a junho, correspondendo ao período chuvoso da região. Os resultados encontrados no presente estudo são semelhantes aos observados em outras populações de caranguejos violinistas e sugerem que a população se encontra estável no ambiente. O presente estudo fornece subsídios para a conservação da espécie no manguezal do Rio Igaraçu.

Palavras-chave: Alometria; Caranguejo violinista; Heteroquelia; Período reprodutivo; Razão sexual 


\section{Abstract}

This study aimed to investigate the population biology of Minuca mordax in the Igaraçu River, Parnaíba, analyzing frequency distribution in size classes, reproductive period, relative growth, morphological sexual maturity, sex ratio and heterochely. The crabs were manually collected, randomly, by two people for 1 hour, in the representative months of the dry season (September to November) and rainy (April to June). In laboratory the crabs were identified, separated according to sex and measured. A total of 610 samples were captured, with 453 males and 157 females. The average size of carapace width $(\mathrm{CW})$ was significantly different $(\mathrm{p}<0.05)$ between males $(17.21 \pm 3.68 \mathrm{~mm})$ and females $(15.06 \pm 3.18 \mathrm{~mm})$. The distribution of the crabs in size classes was unimodal for both sexes. The morphological sexual maturity obtained for males was $12.42 \mathrm{~mm} \mathrm{CW}$ and females was $10.05 \mathrm{~mm} \mathrm{CW}$. The sex ratio for the population was 1:0.35 (male: female), with significant difference from the expected ratio of $1: 1$. The heterochely was observed only in males of the species (224 right-handed and 229 sinister). Subsequently, other on-site observations were carried out monthly, from February/2011 to January/2012 to observe ovigerous females and determine the reproductive period. Females with eggs were observed only from March to June, corresponding to the rainy season in the region. The results found in the present study are similar to those observed in other populations of violinist crabs and suggest that the population is stable in the environment. The present study provides subsidies for the conservation of the species in the Igaraçu River.

Key words: Allometry; Fiddler crab; Heteroquelia; Reproductive period; Sex ratio

\section{Introduction}

The crabs of the genus Minuca (Uca - Leach, 1814), are the most significant members of the estuarine biomass subtropical and tropical regions (BENETTI et al., 2007; MOKHLESI et al., 2011). These animals have an important role in estuarine ecosystem serving as a food source to other organisms and promoting soil bioturbation when they build their burrows in the sediment, which aids in nutrient cycling and energy in the environment (LITULO, 2005a; SCALCO et al., 2016; BECKER et al., 2019; PILLON et al., 2019).

Based on phylogenetic data Shih et al. (2016) recognized all subgenres of $U c a$ as complete genera. In the new classification, nine species are found in Brazil: Leptuca cumulanta (Crane, 1943); L. leptodactyla (Rathbun, 1898); L. thayeri (Rathbun, 1900); Minuca burgersi (Holthuis, 1967); M. mordax (Smith, 1870); M. rapax (Smith, 1870); M. victoriana (von Hagen, 1987), M. vocator (Herbst, 1804) and Uca maracoani (Latreille, 1803).

The species of Minuca are characterized by having sexual dimorphism. The males have as striking feature the presence of a large and a small cheliped. In contrast, females have both small size chelipeds, with similar sizes (COSTA; SOARES-GOMES, 2008; PINHEIRO et al.,
2016). The most cheliped of male may contain up to half the body weight of the animal (ROSENBERG, 2002) and it is used to advertise their presence to potentially receptive females in mating rituals and fighting with other males, in a territorial context (POPE, 2005; MOKHLESI et al., 2011).

Individuals of Minuca genus are active during low tide, returning to their burrows at high tide, and may have different patterns of behavior, mating, feeding preference and microhabitats, so that your ecological niches are not identical (WEIS; WEIS, 2004). The crab M. mordax distribute along the banks of creeks and mangroves, can be found from the Gulf of Mexico to the southeast coast of Brazil (MELO, 1996). According Crane (1975) populations of M. mordax live apparently only the shores of tropical rivers, however, some can live with populations of $M$. burgersi and $M$. rapax in lagoons and estuaries near the open sea.

Studies on the population biology of Minuca crabs are important because they provide relevant information on the ecological stability of the species in a given environment, and allows comparisons between populations of different regions, making it possible to check the differences between them, and also assisting in the understanding of environment in which they live 
(SCALCO et al., 2016; BECKER et al., 2019). In these studies, various aspects are investigated, such as growth, mortality and birth rate, size distributions, temporal dynamics, assessment of density, reproductive period, recruitment and sex ratio (NAKAGAKI; PINHEIRO, 1999; CASTIGLIONI et al., 2006).

In Brazil, the Minuca mordax species had aspects of its population biology studied in Santa Catarina (SCALCO et al., 2016), São Paulo (FRANSOZO et al., 2009) and Paraná (MASUNARI; DISSENHA, 2005; MASUNARI, 2006), and there is no record of studies carried out in the State of Piauí. Thus, this study aimed to investigate the population biology of Minuca mordax in Igaraçu River, Parnaíba-PI, analyzing the relative growth, morphological sexual maturity, frequency distribution in size classes, sex ratio, reproductive period and heterochely.

\section{Material and Methods}

\section{Data collect}

The crabs were collected in an area of approximately $1,430 \mathrm{~m}^{2}$ on the banks of the Igaraçu River (02 53 '59.10"S; 041 $46^{\prime} 48.96^{\prime}$ 'W), in the municipality of Parnaíba, state of Piauí, Brazil (Figure 1). In the collection site is predominant the mud substrate and vegetation consist of macrophytes. This region receives intense human influence due to be located in a tourist area of the city that serves as anchorage for small boats. The region receives a large tourist flow due to the beaches and the Parnaíba River Delta, the third largest in the world (SILVA, 2004).

Samplings were carried out from September 2009 to June 2011, the representative months of the dry season (September to November) and rainy (April to June). The

FIGURE 1: Minuca mordax sampling site on the banks of the Igaraçu River in Parnaíba, state of Piauí, Brazil.

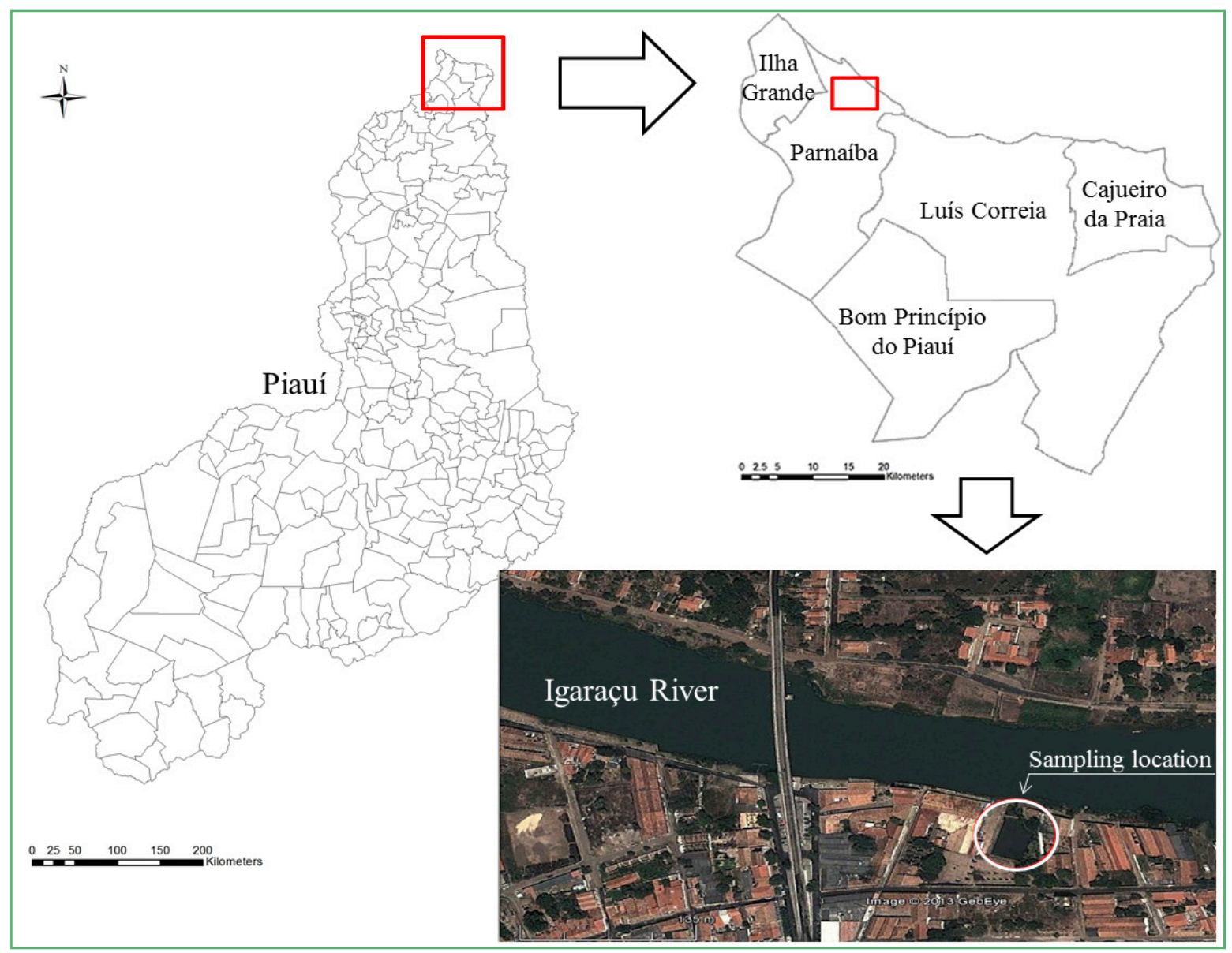


specimens were collected manually at random by two people for 1 hour, during low tide. Crabs inside and outside the burrows were sampled.

After capturing the animals were placed individually in plastic bags and transported to the laboratory where they were kept frozen until the time of analysis. In the laboratory, the animals were defrosted at room temperature, identified according to the key provided by Melo (1996), separated according to sex, and with a caliper $(0.05 \mathrm{~mm}$ accuracy) were measured as the carapace width $(\mathrm{CW})$; body height $(\mathrm{BH})$; abdomen width (AW) in the fourth segment; gonopodium length (GL) of males; bigger cheliped length (BCL) and small cheliped length (SCL) of males, and right and left of the females (RCL and LCL, respectively).

\section{Relative growth}

To study the relative growth, the biometric data obtained were plotted in dispersion graphs using a power equation $\left(\mathrm{y}=\mathrm{ax} \mathrm{x}^{\mathrm{b}}\right)$. It considered the $\mathrm{CW}$ as an independent variable $(\mathrm{x})$. The significance of the values assumed by " $b$ " was tested using t Student test $(\alpha=5 \%)$ (ZAR, 2010). Power equations obtained were linearized by the $\operatorname{logarithmic}$ transformation $(\log \mathrm{y}=\log \mathrm{a}+\mathrm{b} \log \mathrm{x})$. The regressions were made employing the software Regrans (PEZZUTO, 1993).

\section{Morphological sexual maturity}

The determination of the inflection point the dispersion graphic for establishing the morphological sexual maturity was done using the software Regrans (PEZZUTO, 1993). The abdomen width (AW) was used as the dependent variable for females and the bigger cheliped length for males (BCL). The determined inflection point was tested by comparing multiple regressions $(\alpha=5 \%)$ (ZAR, 2010). Based on the morphological sexual maturity found, the animals were grouped into juveniles and adults.

\section{Population structure}

The average size (carapace width $-\mathrm{CW}$ ) of the individuals between the sexes was compared using Student's t-test $(\alpha=5 \%)$. Before any comparison the data were submitted to normality test Shapiro-Wilk $(\alpha=5 \%)(Z A R, 2010)$.

The population structure was analyzed according to the $\mathrm{CW}$ size frequency distribution of all the individuals collected during the study period, according Sturges (1926), dividing the population into 11 size classes with a class interval of $4.71 \mathrm{~mm}$.

\section{Sex ratio}

The sex ratio during the study was determined for the total population and for each $\mathrm{CW}$ size class using the goodness of fit test (Chi-square) $(\alpha=5 \%)$ to verify the sex ratio found to Minuca mordax follows the ratio 1:1 (males: females). For size classes with the total number of individuals below 10 was applied Fisher's exact test $(\alpha=5 \%)(Z A R, 2010)$.

\section{Heterochely}

The values for the length of chelipeds of the crabs were analyzed for normality, using the Shapiro-Wilk test (ZAR, 2010). To check the pairs of chelipeds length heterochely of males and females applied the nonparametric test Mann-Whitney (ZAR, 2010). The same test was also used to verify the difference in the greater length and smaller males cheliped. The evaluation of laterality of the most cheliped males was done using chi-square goodness of fit test (Chi-square) $(\alpha=0.05)$, to verify if the number of males with the greatest cheliped the right and left have the same ratio $(1: 1)$.

\section{Reproductive period}

The analysis of the reproductive period was performed by monthly observations of the presence of ovigerous females, from February 2011 to January 2012. For this, Minuca mordax females were collected at random for one hour. These were put in a plastic container, order to avoid capturing the same individual during sampling. Then observations were made to verify the presence of females with eggs. Soon after, the animals were returned to the environment. 


\section{Results}

A total of 610 individuals was sampled, being 453 males (74.26\%) and 157 females (25.74\%). The carapace width $(\mathrm{CW})$ of the males ranged from 6.35 to $25.10 \mathrm{~mm}$ with average size of $17.21 \pm 3.68 \mathrm{~mm}$. In females the variation was from 6.85 to $22.00 \mathrm{~mm}$, with an average size of $15.06 \pm 3.18 \mathrm{~mm}$. The data relating to the carapace width presented non-normal distribution $(\mathrm{p}<0.05)$, and significant difference between the average size of the $\mathrm{CW}$ of males and females $(\mathrm{p}<0.05)$ with larger males than females (Table 1).

\section{Relative growth}

The results of the analysis of the relative growth of Minuca mordax growth are shown in Table 2, where it was observed that the males showed positive allometric in relation $\mathrm{CW}$ vs. CLC (juvenile $\mathrm{b}=1.823$; adults $\mathrm{b}=1.718$; total $\mathrm{b}=1.795$ ) and CW vs. GL (juvenile $\mathrm{b}=1.202$ ); and females in relation $\mathrm{CW} v$ s. AW (juvenile $\mathrm{b}=1.463$; adult $\mathrm{b}=1.415$; total $\mathrm{b}=1.623$ ) and $\mathrm{CW} v s$. $\mathrm{BH}$ (juvenile $\mathrm{b}=1.374$ ).

TABLE 1: Number and minimum, maximum and mean size of $\mathrm{CW}$ of males and females of Minuca mordax, Igaraçu River in Parnaíba, state of Piauí, Brazil. $\mathrm{M}=$ males; $\mathrm{F}=$ females; $\mathrm{N}=$ number of individuals; $\mathrm{CW}=$ carapace width; $\mathrm{SD}=$ standard deviation.

\begin{tabular}{ccccccc}
\hline Month & Category & N & $\begin{array}{c}\text { Average } \mathbf{C W} \\
(\mathbf{m m})\end{array}$ & SD & $\begin{array}{c}\text { Minimum } \mathbf{C W} \\
(\mathbf{m m})\end{array}$ & $\begin{array}{c}\text { Maximum CW } \\
(\mathbf{m m})\end{array}$ \\
\hline \multirow{2}{*}{ September/2009 } & $\mathrm{M}$ & 34 & 16.63 & 5.09 & 6.35 & 23.70 \\
& $\mathrm{~F}$ & 16 & 12.93 & 4.85 & 6.85 & 20.45 \\
October/2009 & $\mathrm{M}$ & 39 & 18.43 & 4.90 & 6.70 & 24.60 \\
& $\mathrm{~F}$ & 11 & 14.13 & 3.92 & 9.30 & 20.00 \\
November/2009 & $\mathrm{M}$ & 37 & 16.27 & 5.04 & 6.65 & 25.10 \\
& $\mathrm{~F}$ & 13 & 15.12 & 3.20 & 10.25 & 19.75 \\
April/2010 & $\mathrm{M}$ & 43 & 19.40 & 2.97 & 14.00 & 24.65 \\
& $\mathrm{~F}$ & 07 & 17.33 & 1.80 & 14.60 & 20.70 \\
May/2010 & $\mathrm{M}$ & 40 & 17.04 & 2.45 & 12.45 & 22.35 \\
& $\mathrm{~F}$ & 10 & 15.85 & 1.05 & 14.60 & 18.45 \\
June/2010 & $\mathrm{M}$ & 42 & 18.24 & 1.96 & 13.70 & 23.35 \\
& $\mathrm{~F}$ & 08 & 16.50 & 0.80 & 15.30 & 17.45 \\
September/2010 & $\mathrm{M}$ & 07 & 18.32 & 1.94 & 12.75 & 21.20 \\
October/2010 & $\mathrm{F}$ & 43 & 18.39 & 1.12 & 17.00 & 19.75 \\
& $\mathrm{M}$ & 44 & 18.23 & 2.30 & 13.30 & 23.00 \\
November/2010 & $\mathrm{F}$ & 06 & 16.69 & 1.40 & 15.40 & 18.50 \\
April/2011 & $\mathrm{M}$ & 41 & 18.74 & 1.83 & 14.70 & 22.75 \\
& $\mathrm{~F}$ & 09 & 18.71 & 1.92 & 15.95 & 22.00 \\
Mane/2011 & $\mathrm{M}$ & 29 & 13.22 & 2.87 & 9.90 & 13.00 \\
& $\mathrm{~F}$ & 23 & 14.22 & 3.28 & 8.65 & 19.35 \\
& $\mathrm{M}$ & 29 & 13.10 & 2.01 & 7.85 & 18.35 \\
& $\mathrm{~F}$ & 25 & 13.50 & 1.90 & 10.45 & 17.45 \\
& $\mathrm{M}$ & 32 & 15.77 & 2.78 & 10.75 & 23.50 \\
& $\mathrm{~F}$ & 22 & 15.09 & 2.31 & 11.30 & 19.65 \\
\hline
\end{tabular}


TABLE 2: Results of regressions obtained for the population of Minuca mordax in Igaraçu River in Parnaíba, state of Piauí, Brazil. The carapace width $(\mathrm{CW})$ was used as independent variable.

\begin{tabular}{|c|c|c|c|c|c|c|c|}
\hline Relationship & Sex & $\mathbf{N}$ & $\begin{array}{c}\text { Power equation } \\
\quad Y=\mathbf{a x}^{\mathrm{b}}\end{array}$ & $\begin{array}{l}\text { Linearized equation } \\
\ln y=\ln a+b \ln x\end{array}$ & $\mathbf{R}^{2}$ & $\begin{array}{c}t \\
\left(H_{0}: b=1\right)\end{array}$ & Allometry \\
\hline \multirow{2}{*}{$\mathrm{BH}$} & F J & 10 & $\mathrm{BH}=0.254 \mathrm{CW}^{1.374}$ & $\ln \mathrm{BH}=-1.370+1.374 \ln \mathrm{CW}$ & 0.940 & $3.063^{*}$ & + \\
\hline & F A & 147 & $\mathrm{BH}=0.565 \mathrm{CW}^{1.015}$ & $\ln \mathrm{BH}=-0.571+1.015 \ln \mathrm{CW}$ & 0.938 & 0.727 & 0 \\
\hline \multirow{5}{*}{ AW } & F J & 09 & $\mathrm{AW}=0.144 \mathrm{CW}^{1.463}$ & $\ln \mathrm{AW}=-1.938+1.463 \ln \mathrm{CW}$ & 0.914 & $5.175^{*}$ & + \\
\hline & F A & 146 & $\mathrm{AW}=0.201 \mathrm{CW}^{1.415}$ & $\ln \mathrm{AW}=-1.604+1.415 \ln \mathrm{CW}$ & 0.932 & $14.002 *$ & + \\
\hline & F T & 155 & $\mathrm{AW}=0.113 \mathrm{CW}^{1.623}$ & $\ln \mathrm{AW}=-2.180+1.623 \ln \mathrm{CW}$ & 0.962 & $26.689 *$ & + \\
\hline & M J & 51 & $\mathrm{AW}=0.304 \mathrm{CW}^{0.965}$ & $\ln \mathrm{AW}=-1.191+0.965 \ln \mathrm{CW}$ & 0.897 & 0.738 & 0 \\
\hline & M A & 402 & $\mathrm{AW}=0.382 \mathrm{CW}^{0.866}$ & $\ln \mathrm{AW}=-0.962+0.866 \ln \mathrm{CW}$ & 0.942 & $12.455^{*}$ & - \\
\hline \multirow{3}{*}{$\mathrm{BCL}$} & M J & 49 & $\mathrm{BCL}=0.143 \mathrm{CW}^{1.823}$ & $\ln \mathrm{BCL}=-1.945+1.823 \ln \mathrm{CW}$ & 0.907 & $14.297 *$ & + \\
\hline & MA & 393 & $\mathrm{BCL}=0.193 \mathrm{CW}^{1.718}$ & $\ln \mathrm{BCL}=-1.645+1.718 \ln \mathrm{CW}$ & 0.870 & $21.200^{*}$ & + \\
\hline & $\mathrm{MT}$ & 442 & $\mathrm{BCL}=0.154 \mathrm{CW}^{1.795}$ & $\ln \mathrm{BCL}=-1.871+1.795 \ln \mathrm{CW}$ & 0.962 & $49.760^{*}$ & + \\
\hline SCL & M T (nd) & 443 & $\mathrm{SCL}=0.379 \mathrm{CW}^{0.981}$ & $\ln \mathrm{SCL}=-0.970+0.981 \ln \mathrm{CW}$ & 0.940 & 1.566 & 0 \\
\hline \multirow{2}{*}{ LRC } & F J & 06 & $\mathrm{RCL}=0.405 \mathrm{CW}^{0.954}$ & $\ln \mathrm{RCL}=-0.904+0.954 \ln \mathrm{CW}$ & 0.708 & 0.147 & 0 \\
\hline & F A & 147 & $\mathrm{RCL}=0.461 \mathrm{CW}^{0.898}$ & $\ln \mathrm{RCL}=-0.774+0.898 \ln \mathrm{CW}$ & 0.872 & $3.561^{*}$ & - \\
\hline \multirow{2}{*}{ LLC } & F J & 09 & $\mathrm{LCL}=0.474 \mathrm{CW}^{0.868}$ & $\ln \mathrm{LCL}=-0.747+0.868 \ln \mathrm{CW}$ & 0.731 & 0.661 & 0 \\
\hline & F A & 145 & $\mathrm{LCL}=0.428 \mathrm{CW}^{0.917}$ & $\ln L C L=-0.849+0.917 \ln \mathrm{CW}$ & 0.899 & $3.235^{*}$ & - \\
\hline \multirow{2}{*}{ GL } & M J & 50 & $\mathrm{GL}=0.255 \mathrm{CW}^{1.202}$ & $\ln \mathrm{GL}=-1.366+1.202 \ln \mathrm{CW}$ & 0.820 & $2.494 *$ & + \\
\hline & MA & 398 & $\mathrm{GL}=0.620 \mathrm{CW}^{0.859}$ & $\ln \mathrm{GL}=-0.478+0.859 \ln \mathrm{CW}$ & 0.805 & $6.614^{*}$ & - \\
\hline
\end{tabular}

Notes: "nd" means that there was no difference in growth rate between the youth and adult categories, so the categories were grouped; $\mathrm{N}=$ Individuals number; $\mathrm{A}=$ adult; $\mathrm{J}=$ juvenile; $\mathrm{T}=$ total; " $\mathrm{a}$ " and " $\mathrm{b}$ " =, constant; $\mathrm{BH}=$ body height; $\mathrm{AW}=$ abdomen width; $\mathrm{BCL}=$ bigger cheliped length; $\mathrm{SCL}=$ small cheliped length; $\mathrm{LRC}=$ length right cheliped; $\mathrm{LLC}=$ length left cheliped; $\mathrm{GL}=$ gonopodium length; allometry $=$ test for slope $b ; R^{2}=$ coefficient of determination; $t=$ statistical value for the Student's $t$ test; $0=$ isometrics; - = Negative allometry; $+=$ Positive allometry; $*$ Significance $(\mathrm{p}<0.05)$.

\section{Morphological sexual maturity}

Based on the regressions performed, relating $\mathrm{CW}$ vs. BCL for males and CW vs. AW for females (Figure 2), it was determined that the morphological sexual maturity of males occurs with $12.42 \mathrm{~mm} \mathrm{CW}$, and females with $10.05 \mathrm{~mm} \mathrm{CW}$.

FIGURE 2: Dispersion points to the relationship CW vs. BCL and CW vs. AW for a males (A) and females (B) of Minuca mordax, respectively. Black circles = juvenile; white circles $=$ adults; $\mathrm{CW}=$ carapace width; $\mathrm{BCL}=$ bigger cheliped length; $\mathrm{AW}=$ abdomen width)

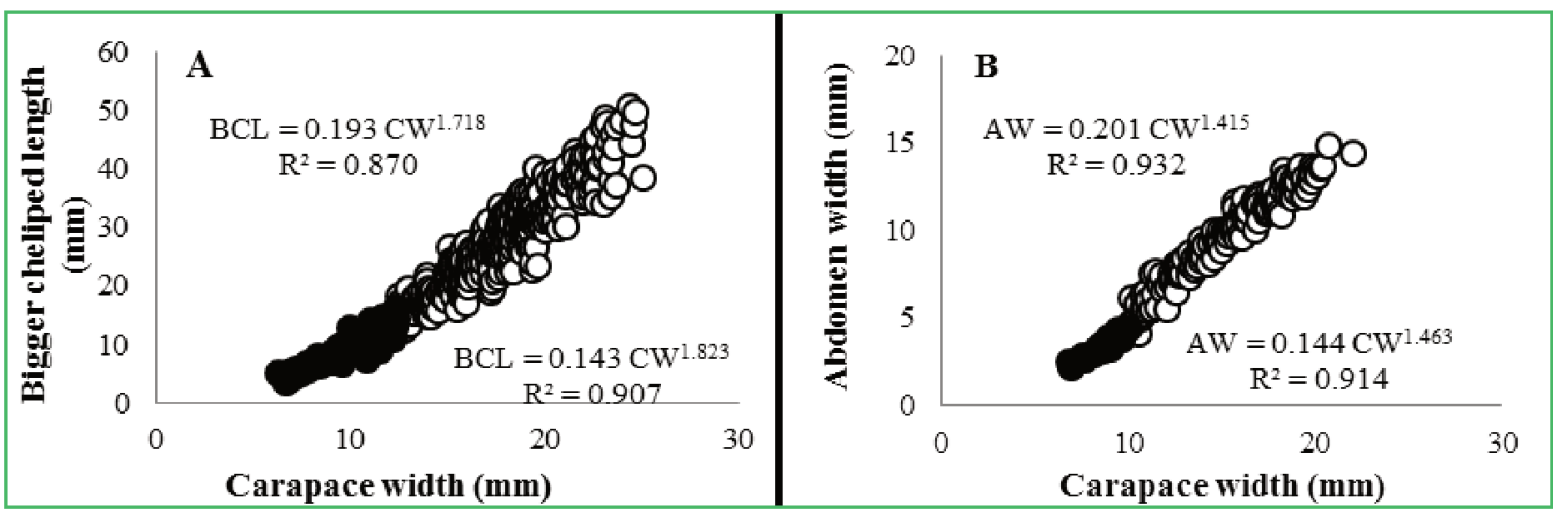




\section{Population structure}

The frequency distribution in size classes was unimodal for males and females (Figure 3). Males were more frequent in class $18.32 \mid--20.03$, and females between classes $14.90 \mid--16.61$ and $16.61 \mid--18.32$.

\section{Sex ratio}

The sex ratio to total crabs examined was 1:0.35 (males:females) and was significantly different $(p<0.05)$ of the expected 1:1 ratio. By analyzing the proportion of males and females in each size class, it was noted that there is significant difference $(\mathrm{p}<0.05)$ in the last six classes (Figure 4 ). In the other classes were maintained at a ratio of $1: 1$.

\section{Heterochely}

The biggest cheliped of males was found on the right (right-handed) in 224 individuals, and the left (sinister) in 229. In the evaluation of laterality of the

FIGURE 3: Frequency distribution in size classes of carapace width of Minuca mordax sampled in Igaraçu River, Parnaíba, state of Piauí. $\mathrm{N}=$ number of individuals.

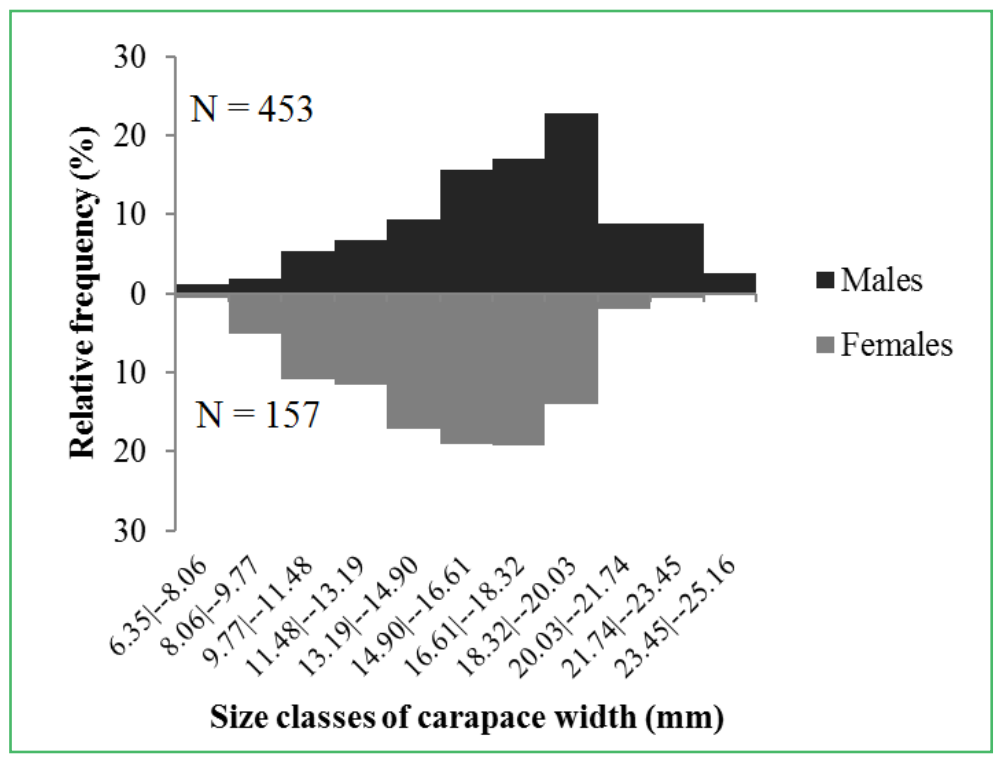

FIGURE 4: Sex ratio of Minuca mordax by size classes of carapace width (mm), sampled in Igaraçu River, Parnaíba, state of Piauí. $(*)$ significant difference between the proportions of males and females $(\mathrm{p}<0.05)$.

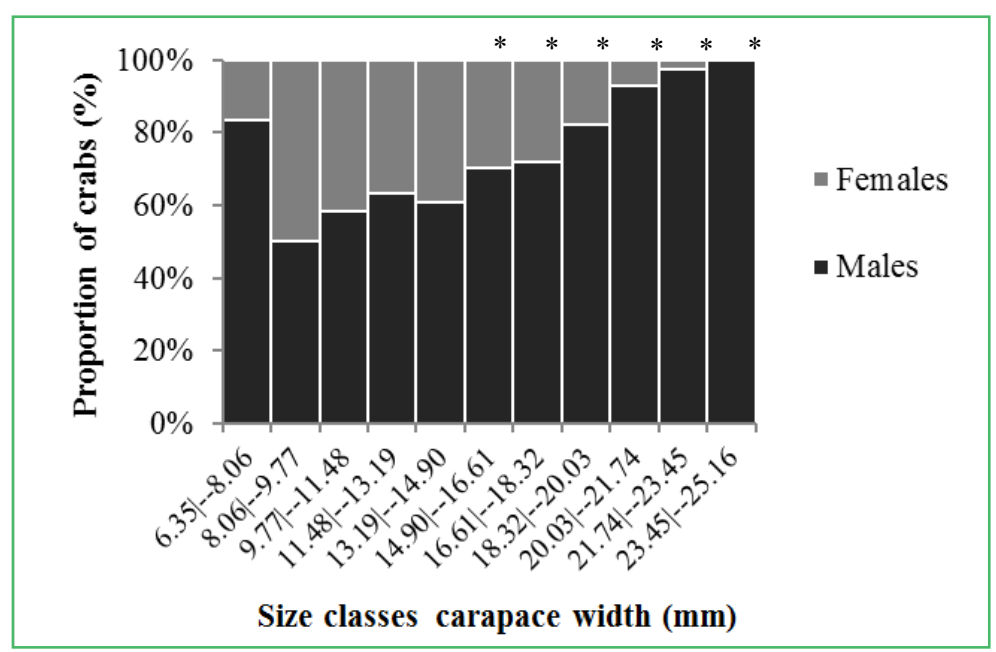


most cheliped of males, it was found that although the number of sinister being higher percentage (sinister: $50.6 \%$; handed: $49.4 \%$ ), statistically the distribution does not differ from the expected ratio of $1: 1(p>0.05)$.

Data concerning to the length of chelipeds present a non-normal distribution $(p<0.05)$. In chelipeds females, there was no significant difference $(p>0.05)$ between the lengths of the right and left. The average size of chelipeds the right side ( $14.72 \pm 11.88 \mathrm{~mm})$ and left $(15.16 \pm 11.85$ $\mathrm{mm}$ ) of males also showed no significant difference $(p>0.05)$. However, a significant difference was observed $(\mathrm{p}<0.05)$ between the lengths of the major and minor cheliped of males.

\section{Reproductive period}

During the monthly observations from February/2011 to January/2012 were registered 206 females. The presence of eggs was observed in 26 animals, from March to June, rainy season in the region (Figure 5). The smallest ovigerous female had $10.45 \mathrm{~mm}$ CW and the largest $18.65 \mathrm{~mm}$.

\section{Discussion}

During ontogeny brachyurans, some changes occur in the external parts of the body, mainly in the abdomen of the females and in the male chelipeds (PRALON; NEGREIROS-FRANSOZO, 2008; MASUNARI et al., 2017). The positive allometry displayed by BCL of males and the AW of females with slight superiority in the juvenile phase may occur due to the necessity of the juvenile reach sexual maturity, to change the size of characters that make possible mating (in males) or egg incubation (in females) (FONTELES-FILHO, 2011). Reinforcing this hypothesis, it may be noted that in males the allometry verified for GL of the juvenile is positive, however, for the adults was observed a negative allometric growth.

The abdomen of females is important in sexual maturity, since such structure becomes wider to protect the mass of eggs during incubation (HARTNOLL, 1982; COBO; FRANSOZO, 1998; MASUNARI et al., 2017). Similarly, the great cheliped of males has an important role in their reproductive behavior for the cohort, mating and territorial defense (ROSENBERG, 2002; BENETTI; NEGREIROS-FRANSOZO, 2004; MASUNARI et al., 2017).

The large cheliped of males develops into until the animal becomes sexually mature (MASUNARI; SWIECH-AYOUB, 2003). The wave of higher cheliped performed by males is an important criterion in their choice by females during the breeding season (LATRUFFE et al., 1999). Males can use their chelipeds as a tool to maintain and manipulate the females during copulation (PRALON; NEGREIROS-FRANSOZO, 2008).

FIGURE 5: Absolute frequency of Minuca mordax females observed in loco in Igaraçu River, Parnaíba, state of Piauí.

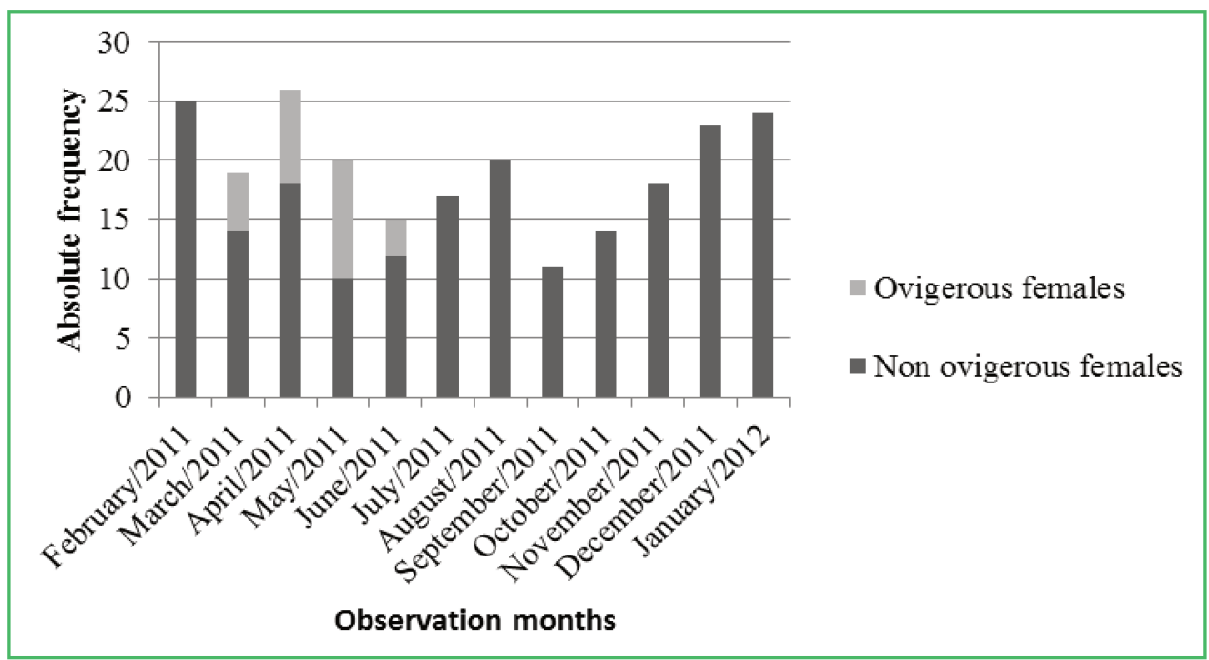


In this study, the levels of allometry of BCL the $M$. mordax males (juvenile $\mathrm{b}=1.823$ and adults $\mathrm{b}=1.718$ ) are considerably higher when compared to the AW of females (juvenile $b=1.463$ and adults $b=1.415$ ), as observed by Masunari and Dissenha (2005). This occurs due to the chelipeds constitute independent structures and are not restricted functionally the size of the other organs structures. Furthermore, chelipeds provides greater advantages for the males of the species. However, the abdomen of the female is not an independent structure, which can only work together with the sternum, which indicates that any disproportionate increase in width will result in reducing the efficiency of its mechanism, making difficult the movement of pereiopods during walks (HARTNOLL, 1982; MASUNARI; DISSENHA, 2005).

The BH of adult females also showed positive allometric growth. One can infer that the adult female is a rise in the growth rate of the $\mathrm{BH}$ as adjusted after the puberty molt to maintain gonadal mass. The differences in the growth process after the puberty molt can be evidenced in the dimensions of the carapace as a result of the development of the gonads (BENETTI; NEGREIROS-FRANSOZO, 2004; BECKER et al., 2019). This type of alteration can be associated with changes in the endocrine system, which are also related to reproductive maturation process, differentiating juvenile and adult stages (HARTNOLL, 1982).

Regarding the smaller cheliped males and both chelipeds of females M. mordax, its main function is to collect a small amount of material from the substrate, and carry it to the mouth for feeding (ROSENBERG, 2002; AZEVEDO et al., 2017). This may account for the fact of these appendixes present isometric or negative allometric growth, since growth in large proportions impair the operation of the feed mechanism.

It can be verified that the smallest ovigerous female (10.45 mm CW) found, was slightly higher than the value determined for the morphological sexual maturity, which may suggest how appropriate the Regrans software in the process of determining the morphological sexual maturity. It is emphasized that the study of morphological sexual maturity only provides some indication of the size of the physiological sexual maturity of the animal. Only the examination of the reproductive system allows us to infer more precisely the size that is established sexual maturity (GÓES; FRANSOZO, 1997).

In other studies with Minuca crabs, males also reached the morphological sexual maturity with superior size to of females (MASUNARI; SWIECH-AYOUB, 2003; BENETTI; NEGREIROS-FRANSOZO, 2004; MASUNARI; DISSENHA, 2005; MASUNARI et al., 2005; CASTIGLIONI et al., 2006; COSTA; SOARESGOMES, 2008; PRALON; NEGREIROS-FRANSOZO, 2008; FRANSOZO et al., 2009).

The morphological sexual maturity to M. mordax was also determined by other researchers in other regions of Brazil, with results similar to those obtained in this study. Masunari and Dissenha (2005), in Paraná, determined that males reach morphological sexual maturity with $11.70 \mathrm{~mm} \mathrm{CW}$ and females with $8.77 \mathrm{~mm}$. Fransozo et al. (2009), in São Paulo, determined that the puberty molt occurs with $11.90 \mathrm{~mm} \mathrm{CW}$ for males and $11.50 \mathrm{~mm}$ for females.

The frequency distribution in size classes of the population was unimodal, suggesting a stable pattern in its composition, recruitment, migration and mortality (LITULO, 2005a; BECKER et al., 2019; PILLON et al., 2019). The unimodality is a common fact for populations of Minuca crabs in tropical regions (LITULO, 2005b; BEZERRA; MATTHEWS-CASCON, 2006; BECKER et al., 2019; PILLON et al., 2019).

The larger size of males compared to females, observed in this study may be related to different deviations of power between the sexes. While males invest most of their energy to somatic growth, females direct large part of his energy into reproductive events to use this feature in the production and incubation of eggs. Females also make no growing molt while they are ovigerous, what condition the slower growth compared to (JOHNSON, 2003; COLPO; NEGREIROSFRANSOZO, 2004; HARTNOLL, 2006). This fact also occurs in populations of Austruca láctea annulipes, Leptuca leptodactyla, Minuca rapax, A. annulipes, U. maracoani, and M. mordax (LITULO, 2005a; BEZERRA; MATTHEWS-CASCON, 2006; CASTIGLIONI et al., 2006; MOKHTARI et al., 2008; 
DI BENEDETTO; MASUNARI, 2009; SCALCO et al., 2016; BECKER et al., 2019).

The deviation occurred in the sex ratio favoring males is common in crab populations of genus Minuca and Austruca. The predominance of males in the population also occurs in M. mordax, M. vocator; $A$. annulipes, A. lactea annulipe and M. rapax (COLPO; NEGREIROS-FRANSOZO, 2004; LITULO, 2005a; MOKHTARI et al., 2008; COSTA; SOARES-GOMES, 2008; SCALCO et al., 2016; BECKER et al., 2019; PILLON et al., 2019). Alterations in the proportion of males and females can be the result of differences in spatial or temporal distribution of individuals; different mortality (WADA et al., 2000); patterns of different migration; food restrictions; exposure to predators; use of different habitats; uneven growth rates; and distinct behavior patterns (CHRISTY; SALMON, 1984; BECKER et al., 2019; PILLON et al., 2019).

The males of M. mordax heterochely present status, however there were no predominance of larger cheliped on either side, that is, it has no tendency to grow to the right or left. Hartnoll (1988) explains that the species of the genus Minuca heterochely is limited to male and these animals do not usually show laterality. The largest chelipode is of great importance during the reproductive period for making waves to attract females (PINHEIRO et al., 2016). Most of the populations of this genus, males have a proportional abundance of large cheliped the left and right (SHIH et al., 1999; COSTA; SOARESGOMES, 2008). Only a few species of the genus are beyond the rule of the ratio of $1: 1$, as referenced by Rosenberg (2002) and Masunari and Dissenha (2005), and as noted by Pillon et al. (2019) in L. cumulanta and L. leptodactyla.

Regarding reproduction frequency Sastry (1983) reported that crustaceans can reproduce during every month of the year (continuous pattern), or only during the months with more favorable environmental conditions (discontinuous or seasonal pattern). In this study, the females with eggs were found only in the rainy months, indicating that possibly their reproduction follows a seasonal pattern. Other species of the fiddler crab also feature seasonal reproduction, such as: Minuca pugnax, Leptuca pugilator and L. thayeri (CHRISTY; SALMON, 1984; GREENSPAN, 1982; COSTA; NEGREIROS-FRANSOZO, 2003). According Litulo (2005c), spawns during the rainy season can provide an advantage to populations brachyuran because the period with higher levels of precipitation can cause changes in water salinity and promote the increase in the concentration of nutrients. This provides the increased primary productivity in the environment, which is favors development of planktonic larvae of brachyuran (MANTELATTO et al., 2003).

However, Becker et al. (2019) observed that the recruitment period for $M$. rapax occurs continuously, with greater intensity in the rainy season, and related the low frequency of ovigerous females to the breeding strategy in which the females stay in their dens during the incubation period of the eggs. This fact has also been described for M. mordax (FRANSOZO et al., 2009). Changes in the natural characteristics of the ecosystem, such as habitat loss, may have a direct influence on the recruitment, growth and reproduction of this and other species, which makes it urgent, therefore, to maintain the natural areas that are under constant threat of anthropogenic disturbance (SCALCO et al., 2016).

Based on the results it was observed that the population of M. mordax studied has a relatively stable pattern and also displays a common model to genus with regard to sex ratio and heterochely condition. Thus, the information referred to in this study reveal important elements of the species biology, and can assist in proposals for conservation of the species in the region, given that it inhabits a place with human influence.

\section{Acknowledgements}

To Dr. Paulo Ricardo Pezzuto the availability of Regrans software and guidance on their use. CNPq for scientific initiation scholarship granted during the research under the Project Bioecology decapod crustaceans in the area of Environmental Protection of the Parnaiba Delta, State of Piaui, Brazil. 


\section{References}

AZEVEDO, D. S.; SILVA, J. V. C. L.; CASTIGLIONI, D. S. Population biology of Uca maracoani in a tropical mangrove. Thalassas, Santiago de Compostela, v. 33, n. 1, p. 1-13, 2017.

BECKER, J.; SILVA CASTIGLIONI, D.; OZGA, A. V. Biologia populacional de Minuca rapax (SMITH, 1870) (Crustacea, Decapoda, Ocypodidae) em um manguezal do nordeste brasileiro. Revista Nordestina de Zoologia, João Pessoa, v. 12, n. 1, p. 6591, 2019.

BENETTI A. S.; NEGREIROS-FRANSOZO, M. L. Relative growth of Uca burgersi (Crustacea, Ocypodidae) from two mangroves in the southeastern Brazilian coast. Iheringia, Porto Alegre, v. 94, n. 1, p. 67-72, 2004.

BENETTI, A. S.; NEGREIROS-FRANSOZO, M. L.; COSTA, T. M. Population and reproductive biology of Uca burgersi Holthuis, 1967 (Crustacea, Brachyura) in three subtropical mangrove forests. Revista de Biología Tropical, San José, v. 55, p. 55-70, 2007.

BEZERRA, L. E. A.; MATTHEWS-CASCON, H. Population structure of the fiddler crab Uca leptodactyla Rathbun 1898 (Brachyura: Ocypodidae) in a tropical mangrove of northeast Brazil. Thalassas, Santiago de Compostela, v. 22, n. 1, p. 65-74, 2006.

CASTIGLIONI, D. S.; NEGREIROS-FRANSOZO, M. L.; MORTARI, R. C. Biologia populacional do caranguejo violinista Uca rapax (Smith, 1870) (Crustacea, Ocypodoidea), proveniente de uma área de manguezal degradado em Paraty, RJ, Brasil. Atlântica, Rio Grande, v. 28, n. 2, p. 73-8, 2006.

CHRISTY, J. H.; SALMON, M. Ecology and evolution of mating systems of fiddler crabs (Genus Uca). Biological Review, Cambridge, v. 59, p. 483-509, 1984.

COBO, V. J.; FRANSOZO, A. Relative growth of Goniopsis cruentata (Crustacea, Brachyura, Grapsidae), on the Ubatuba region, São Paulo, Brazil. Iheringia, Porto Alegre, v. 84, n. 1, p. 21-28, 1998.

COLPO, K. D.; NEGREIROS-FRANSOZO, M. L. Comparison of the population structure of the fiddler crab Uca vocator (Herbst, 1804) from three subtropical mangrove forests. Scientia Marina, Barcelona, v. 68, n. 1, p. 139-146, 2004.

COSTA, T. M. C.; NEGREIROS-FRANSOZO, M. L. Population biology of Uca thayeri Rathbun, 1900 (Brachyura, Ocypodidae) in subtropical South American mangrove area: results from transect and catch-per-unit-effort techniques. Crustaceana, Leiden, v. 75, n. 10, p. 1201-1218, 2003.

COSTA, T. M. M.; SOARES-GOMES, A. Relative growth of the fiddler crab Uca rapax (Smith) (Crustacea: Decapoda: Ocypodidade) in a tropical lagoon (Itaipú), Southeast Brazil. PanAmerican Journal of Aquatic Sciences, Rio Grande, v. 3, n. 2, p. 94-100, 2008.

CRANE, J. Fiddler crabs of the world. Ocypodidae: Genus Uca. Princeton: Princeton University Press, 1975. 424 p.

DI BENEDETTO, M.; MASUNARI, S. Estrutura populacional de Uca maracoani (Decapoda, Brachyura, Ocypodidae) no Baixio Mirim, Baía de Guraratuba, Paraná. Iheringia, Porto Alegre, v. 99, n. 4, p. 381-389, 2009.
FONTELES-FILHO, A. A. Oceanografia, biologia e dinâmica populacional de recursos pesqueiros. Fortaleza: Expressão Gráfica e Editora, 2011. 464 p.

FRANSOZO, V. C.; MORTARI, R. C.; BENETTI, A. S. Population biology of Uca mordax (Smith, 1870) (Crustacea, Decapoda, Ocypodidae) from the southeastern coast of Brazil. Estudos de Biologia, Curitiba, v. 31, n. 73/75, p. 23-31, 2009.

GÓES, J. M.; FRANSOZO, A. Relative growth of Eriphia gonagra (Fabricius, 1781) (Crustacea, Decapoda, Xanthidae) in Ubatuba, State of São Paulo, Brazil. Nauplius, Porto Alegre, v. 5, n. 2, p. 85-98, 1997.

GREENSPAN, B. N. Semi-monthly reproductive cycles in male and female of fiddler crabs, Uca pugnax. Animal Behaviour, St Andrews, v. 30, n. 4, p. 1084-1092, 1982.

HARTNOLL, R. G. Growth. In: BLISS, D. E. (Ed.). The biology of Crustacea: Embryology, Morphology and Genetics. Vol. 2. New York: Academic Press, 1982. p. 111-196.

HARTNOLL, R. G. Growth and molting. In: BURGGREN, W. W.; MCMAHON, B. R. (Ed.). Biology of the land crabs. Cambridge: Cambridge University Press, 1988. p. 186-209.

HARTNOLL, R. G. Growth and molting. Hydrobiologia, Brussels, v. 557, p. 31-40, 2006.

JOHNSON, P. T. J. Biased sex ratios in fiddler crabs (Brachyura, Ocypodidae): a review and evaluation of the influence of sampling method, size class, and sex-specific mortality. Crustaceana, Leiden, v. 76, n. 5, p. 559-580, 2003.

LATRUFFE, C.; MCGREGOR, P. K.; OLIVEIRA, R. F. Visual signalling and sexual selection in male fiddler crabs, Uca tangeri. Marine Ecology Progress Series, Oldendorf, v. 189, p. 233-240, 1999.

LITULO, C. Population biology of the fiddler crab Uca annulipes (Brachyura: Ocypodidae) in a tropical East African Mangrove (Mozambique). Estuarine, Coastal and Shelf Science, New York, v. 62, n. 1-2, p. 283-290, 2005a.

LITULO, C. Population structure and reproductive biology of the fiddler crab Uca inversa (Hoffman, 1874) (Brachyura: Ocypodidae). Acta Oecologica, Paris, v. 27, n. 3, p. 135-141, 2005 b.

LITULO, C. External factors determining the reproductive periodicity in a tropical population of the hairy crab Pilumnus vespertilio (Decapoda: Brachyura: Pilumnidae). The Raffles Bulletin of Zoology, Singapura, v. 53, n. 1, p. 115-118, $2005 \mathrm{c}$.

MANTELATTO, F. L. M.; FARIA, F. C. R.; GARCIA, R. B. Biological aspects of Mithraculus forceps (Brachyura: Mithracidae) from Anchieta Island, Ubatuba, Brazil. Journal of the Marine Biological Association of the United Kingdom, Cambridge, v. 83, n. 4, p. 789-791, 2003.

MASUNARI, S. Distribuição e abundância dos caranguejos $U c a$ Leach (Crustacea, Decapoda, Ocypodidae) na Baía de Guaratuba, Paraná, Brasil. Revista Brasileira de Zoologia, Curitiba, v. 23, n. 4, p. 901-914, 2006.

MASUNARI, S.; DISSENHA, N. Alometria no crescimento de Uca mordax (Smith) (Crustacea, Decapoda, Ocypodidae) na Baía de Guaratuba, Paraná, Brasil. Revista Brasileira de Zoologia, Curitiba, v. 22, n. 4, p. 984-990, 2005.

MASUNARI, S.; DISSENHA, N.; FALCÃO, R. C. Crescimento relativo e destreza dos quelípodos em Uca maracoani (Crustacea, 
Decapoda, Ocypodidae) no Baixo Mirím, Baía de Guaratuba, Paraná, Brasil. Revista Brasileira de Zoologia, Curitiba, v. 22, n. 4, p. 974-983, 2005.

MASUNARI, S.; SWIECH-AYOUB, B. D. E. P. Crescimento relativo em Uca leptodactyla Rathbun (Crustacea, Decapoda, Ocypodidae). Revista Brasileira de Zoologia, Curitiba, v. 20, n. 3, p. 487-91, 2003.

MASUNARI, S.; MARTINS, S. B.; MAROCHI, M. Z.; SERRA, W. S.; SCARABINO, F. Morphological variability in populations of the fiddler crab Leptuca uruguayensis (Nobili, 1901) (Crustacea, Decapoda, Ocypodidae) from South America. Brazilian Journal of Oceanography, São Paulo, v. 65, n. 3, p. 373-381, 2017.

MELO, G. A. S. Manual de Identificação dos Brachyura (caranguejos e siris) do litoral brasileiro. São Paulo: Editora Plêiade FAPESP, 1996. 603 p.

MOKHLESI, A.; KAMRANI, E.; BACKWELL, P.; SAJJADI, M. Study on the behaviour of two fiddler crabs, Uca sindensis and Uca annulipes (Decapoda: Ocypodidae), in Bandar Abbas, Iran. Journal of the Marine Biological Association of the United Kingdom, Cambridge, v. 91, n. 1, p. 245-249, 2011.

MOKHTARI, M.; SAVARI, A.; REZAI, H.; KOCHANIAN, P.; BITAAB, A. Population ecology of fiddler crab, Uca lacteal annulipes (Decapoda, Ocypodidae) in Sirik mangrove estuary, Iran. Estuarine, Coastal and Shelf Science, New York, v. 76, n. 2, p. 273-281, 2008.

NAKAGAKI, J. M.; PINHEIRO, M. A. A. Biologia populacional de Emerita brasiliensis Schmitt (Crustacea, Hippidae) na Praia Vermelha do Norte Ubatuba (São Paulo, Brasil). Revista Brasileira de Zoologia, Curitiba, v. 16, n. 2, p. 83-90, 1999.

PEZZUTO, P. R. REGRANS: a "basic" program for an extensive analysis of relative growth. Atlântica, Rio Grande, v. 15, n. 1, p. 93-105, 1993

PILLON, C. F.; GONÇALVES, A. S.; SANTOS, S. Estrutura populacional de duas espécies de caranguejos chama-marés (Crustacea: Decapoda: Ocypodidae) em um manguezal no nordeste do Brasil. Revista Nordestina de Zoologia, João Pessoa, v. 12, n. 1, p. 92-122, 2019.

PINHEIRO, M. A. A.; MASUNARI, S.; BEZERRA, L. E. A.; SANTANA, W.; PIMENTA, C. E. R. Avaliação dos caranguejos chama-maré (Decapoda: Ocypodidae). In: PINHEIRO, M.; BOOS, H. (Org.). Livro vermelho dos crustáceos do Brasil: avaliação 2010-2014. Porto Alegre: Sociedade Brasileira de Carcinologia, 2016. p. 233-251

POPE, D. Waving in a crowd: fiddler crabs signal in networks. In: MCGREGOR, P. K. (Ed.). Animal Communication Nerworks. Cambridge: Cambridge University Press, 2005. p. 252-276.
PRALON, B. G. N.; NEGREIROS-FRANSOZO, M. L. Relative growth and morphological sexual maturity of Uca cumulanta (Crustacea, Decapoda, Ocypodidae) from a tropical Brazilian mangrove population. Journal of the Marine Biological Association of the United Kingdom, Cambridge, v. 88, n. 3, p. 569-574, 2008.

ROSENBERG, M. S. Fiddler crab claw shape variation: a geometric morphometric analysis across the genus Uca (Crustacea: Brachyura: Ocypodidae). Biological Journal of the Linnean Society, London, v. 75, n. 2, p. 47-162, 2002.

SASTRY, A. N. Ecological aspects of reproduction. In: VERNBERG, W. B. (Ed.). The Biology of Crustacea. Environmental Adaptations. Vol. 8. New York: Academic Press, 1983. p. 197-270.

SCALCO, A. C. S.; RAMOS, C. A.; BOOS, H. Estrutura populacional de Uca (Minuca) mordax (Smith, 1870)(Decapoda: Ocypodidae) em um sistema estuarino impactado no Sul do Brasil. Revista CEPSUL - Biodiversidade e Conservação Marinha, Itajaí, v. 5, p. 17-28, 2016.

SHIH, H. T.; MOK, H. K.; CHANG, H. W.; LEE, S. C. Morphology of Uca formosensis, 1921 (Crustacea: Decapoda: Ocypodidae), an endemic fiddler crab from Taiwan, with notes on its ecology. Zoological Studies, Taipei, v. 38, n. 2, p. 164-177, 1999.

SHIH, H. T.; NG, P. K.; DAVIE, P. J.; SCHUBART, C. D.; TÜRKAY, M.; NADERLOO, R.; LIU, M. Y. Systematics of the family Ocypodidae Rafinesque, 1815 (Crustacea: Brachyura), based on phylogenetic relationships, with a reorganization of subfamily rankings and a review of the taxonomic status of $U \mathrm{ca}$ Leach, 1814, sensu lato and its subgenera. Raffles Bulletin of Zoology, Singapore, v. 64, p. 139-175, 2016.

SILVA, M. F. L. O Ecoturismo no Delta do Parnaíba-PI e entorno: turismo e sustentabilidade. 2004. 93 f. Trabalho de conclusão de curso (Especialização) - Universidade de Brasília, Centro de Excelência em Turismo, Brasília, 2004.

STURGES, H. A. The choice of a class interval. Journal of the American Statistical Association, Alexandria, v. 21, n. 153, p. $65-$ 66, 1926.

WADA, S.; ASHIDATE, M.; YOSHINO, K.; SATO, T.; GOSHIMA, $\mathrm{S}$. Effects of sex ratio on egg extrusion frequency and mating behaviour of the spiny king crab Paralithodes brevipes (Decapoda: Lithodidae). Journal of Crustacean Biology, Gloucester Point, v. 20, n. 3, p. 479-482, 2000.

WEIS, J.; WEIS, P. Behavior of four species of fiddler crabs, genus $U c a$, in Southeast Sulawesi, Indonesia. Hydrobiologia, Brussels, v. 523, n. 1 p. $47-58,2004$.

ZAR, J. H. Biostatistical analysis. New Jersey: Prentice Hall, 2010. 944 p. 